\title{
Marine Cryptophytes Are Great Sources of EPA and DHA
}

\author{
Elina Peltomaa ${ }^{1, *}$ (D), Matthew D. Johnson ${ }^{2}$ and Sami J. Taipale ${ }^{3}$ \\ 1 Department of Environmental Sciences, University of Helsinki, Niemenkatu 73, 15140 Lahti, Finland \\ 2 Biology Department, Woods Hole Oceanographic Institute, 266 Woods Hole Road, \\ Woods Hole, MA 02543, USA; mattjohnson@whoi.edu \\ 3 Department of Biological and Environmental Science, University of Jyväskylä, P.O. Box 35 (YA), \\ 40014 Jyväskylä, Finland; sami.taipale@jyu.fi \\ * Correspondence: elina.peltomaa@helsinki.fi; Tel.: +358-50-448-6649
}

Received: 23 November 2017; Accepted: 18 December 2017; Published: 26 December 2017

\begin{abstract}
Microalgae have the ability to synthetize many compounds, some of which have been recognized as a source of functional ingredients for nutraceuticals with positive health effects. One well-known example is the long-chain polyunsaturated fatty acids (PUFAs), which are essential for human nutrition. Eicosapentaenoic acid (EPA) and docosahexaenoic acid (DHA) are the two most important long-chain omega-3 ( $\omega-3)$ PUFAs involved in human physiology, and both industries are almost exclusively based on microalgae. In addition, algae produce phytosterols that reduce serum cholesterol. Here we determined the growth rates, biomass yields, PUFA and sterol content, and daily gain of eight strains of marine cryptophytes. The maximal growth rates of the cryptophytes varied between $0.34-0.70$ divisions day ${ }^{-1}$, which is relatively good in relation to previously screened algal taxa. The studied cryptophytes were extremely rich in $\omega-3$ PUFAs, especially in EPA and DHA (range 5.8-12.5 and 0.8-6.1 $\mu \mathrm{g}$ mg dry weight ${ }^{-1}$, respectively), but their sterol concentrations were low. Among the studied strains, Storeatula major was superior in PUFA production, and it also produces all PUFAs, i.e., $\alpha$-linolenic acid (ALA), stearidonic acid (SDA), EPA, and DHA, which is rare in phytoplankton in general. We conclude that marine cryptophytes are a good alternative for the ecologically sustainable and profitable production of health-promoting lipids.
\end{abstract}

Keywords: microalgae; polyunsaturated fatty acids; omega-3; omega-6; sterols; functional foods; nutraceuticals

\section{Introduction}

Consumers' growing awareness of healthy products has promoted the development of novel natural sources of functional ingredients. Microalgae have been suggested to be among the most promising sources, since they can be used to produce many kinds of biomolecules with high nutraceutical value [1-3]. Microalgae can be grown in controlled conditions, allowing the production of biomass with a constant biochemical composition and eliminating the risk of chemical contamination of the biomass. Thus, the biotechnology of microalgae has gained considerable importance in recent decades.

To date, many commercial nutraceuticals, dietary supplements, and functional ingredients as well as pigments are produced using green algae, e.g., Chlorella, and cyanobacteria, e.g., Spirulina. These taxa are fast growing and rich in, for example, amino acids, but they are low in some of the most desirable biomolecules such as long-chain polyunsaturated omega-3 fatty acids ( $\omega-3$ PUFAs), which are a specific group of polyunsaturated fatty acids in which the first double bond is located between the third and fourth carbon atom counting from the methyl end of the fatty acid. Only plants can synthesize PUFAs, which means that consumers must obtain them from their diet [4]. 
The four types of $\omega-3$ PUFAs mostly involved in human physiology are $\alpha$-linolenic

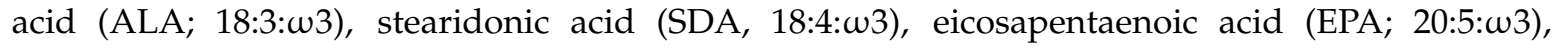
and docosahexaenoic acid (DHA; 22:6:w3). The long-chain EPA and DHA can be obtained only from certain organisms, mainly of aquatic origin, whereas all terrestrial plants produce and contain fairly high amounts of ALA, which is the precursor to the $\omega-3$ series fatty acids (FAs) [5]. The human body cannot produce short-chain $\omega-3$ on its own, and converts the short-chain $\omega-3$ to the long-chain versions, especially DHA, inefficiently (i.e., only $3-4 \%$ is converted) [4]. Thus, EPA and DHA are often determined as essential dietary nutrients. They are both needed for normal metabolism, and they have been implicated in the reduction of cardiovascular diseases like arrhythmia, stroke, and high blood pressure, and can ameliorate renal diseases, depression, dementia, rheumatoid arthritis, and asthma, and are essential for normal fetal brain development as well as growth and development of infants/children [1,6].

The $\omega-6$ PUFAs have been shown to promote health in some cases, e.g., reduce nerve pain of diabetic patients and help boys with symptoms of attention deficit hyperactivity disorder (ADHD) $[7,8]$; however, excess dietary gain of $\omega-6$ PUFAs is known to promote cardiovascular disease, cancer, and inflammatory and autoimmune diseases in humans [9]. In the Western diet, $\omega-6$ PUFA consumption has become progressively much higher than that of $\omega-3$ PUFA due to increased consumption of vegetable oils rich in linoleic acid (LA; 18:2w6; precursor of the long chain $\omega-6$ FAs) [10]. The optimal dietary $\omega-6 / \omega-3$ ratio should be around 1-4:1, but in the Western diet it varies between 10:1 and 20:1 [11,12]. This is significant, since both $\omega-6$ and $\omega-3$ elongation need the same enzymes and, thus, in humans, the excess consumption of $\omega-6$ FAs reduces the already low conversion rate of short-chain $\omega-3$ ALA to long-chain EPA and DHA by 40-50\% [13].

So far, fish oil has been the main commercial source of EPA and DHA, but alternative sources are needed since the global consumer needs cannot be satisfied by the current global fish stock harvests, and also the practice of using fish as feed at fish farms is nonsustainable. Furthermore, fish oil is not suitable for vegetarians or people allergic to fish, it has an odor unpleasant to some people, and it may contain lipid-soluble environmental pollutants. Fish oil quality also varies depending on the fish species, season, and geographical location [14]. Like humans, fish obtain EPA and DHA from their diet, basically from microalgae, some of which could be used in commercial PUFA production.

Besides PUFAs, many algae are also rich in other lipids, such as phytosterols. Phytosterols have chemical structures similar to cholesterol, but they are effective in reducing serum cholesterol levels, and they may also prevent Alzheimer's disease, suppress the growth of colonic tumors, and have beneficial effects on prostate disorders [15,16]. Stigmasterol, campesterol, and sitosterol are the main molecular species of phytosterols, and stigmasterol is claimed to be the most valuable of these three due to its health-promoting benefits [17]. Phytosterols can be found both in terrestrial and aquatic plants and algae. Similar to $\omega-3$ PUFAs, dietary consumption is the only source of phytosterols found in plasma of humans [18].

Even though microalgae are potentially very promising sources of lipids, the present challenge is to find an economically viable way to use them for lipid production, and searching for the most suitable species/strains plays an important role in this. Currently, Nannochloropsis (eustigmatophyte) species are suggested to be among the most promising EPA and DHA producers for commercial applications [2,19]. However, many microalgae are known to be able to accumulate lipids in high amounts, and high EPA and DHA concentrations have been detected in both marine and fresh waters in cryptophytes, dinoflagellates, and diatoms [20]. These three groups represent distinct phylogenetic branches in the eukaryotic tree of life relative to green algae [21,22], and, thus, likely produce unique cocktails of nutraceuticals.

Due to their high PUFA, sterol, and amino acid concentrations, the nutritional value of cryptophytes has been proven to be of utmost importance in aquatic food webs [1,23-25]. This suggests that cryptophyte algae could offer a potential source of lipids also for nutraceutical purposes. There are already several publications reporting high PUFA concentrations in cryptophytes; however, 
most of these studies do not report the total amounts of FAs per biomass but only PUFA percentages of the total FAs [1,26-28]. Similarly, most studies investigating FA content and composition in microalgae do not report growth rates. This may give the wrong impression of their potential in profitable PUFA production. Most cryptophytes are known to grow fairly slowly (growth rates well below 0.8 div. day $\left.{ }^{-1}\right)[27,29,30]$, which may hinder their usability in commercial production. However, in suitable conditions some strains are reported to have higher growth rates (e.g., 1.2 div. day ${ }^{-1}$ ) [31]. The cell size of most cryptophyte species is small (below $500 \mu \mathrm{m}^{3}$ ), and they do not possess heavy cell wall structures, which means that the cell biomass is low compared with that of many diatoms and dinoflagellates. However, due to the lack of recalcitrant cell wall, cryptophytes are easier to break and process further for commercial purposes than diatoms, dinoflagellates, or, for example, Nannochloropsis [32]. Since the cultivation of marine algae has the benefits of using non-potable water and non-arable land, we chose to focus on marine cryptophytes in this study. We analyzed the PUFA and sterol contents of eight marine cryptophyte strains and estimate their usability (e.g., growth rate and biomass production) for commercial lipid production.

\section{Results and Discussion}

\subsection{Growth and Biomass Production}

As expected, all species showed moderate growth rates between $0.34-0.70$ div. day ${ }^{-1}$ in the exponential growth phase (Table 1). However, the growth rates were very well comparable with the ones detected for Nannochloropsis species, (0.04-0.60 div. day $\left.{ }^{-1}\right)$ [19]. Similarly, the observed growth rates were competitive with strains of polar and temperate microalgae, including the prymnesiophyte Emiliania huxleyi, prasinophyte Pyramimonas sp., and the raphidophyte Fibrocapsa japonica. The diatoms Chaetoceros brevis and Thalassiosira weissflogii have been suggested for EPA and DHA production by Bolen et al. [33] and also have lower growth rates (range 0.14-0.49 div. day ${ }^{-1}$ ), as do tropical Nannochloropsis sp., Isochrysis sp., and Tetraselmis sp., which have been suggested for scale-up production by Huerlimann et al. [34] (range $0.10-0.41$ div. day ${ }^{-1}$ ). The daily volumetric biomass yields of the cryptophyte strains differed remarkably, being highest in Chroomonas mesostigmatica and Storeatula major (3.40 and $3.23 \mathrm{mg}$ dry weight (DW) $\mathrm{L}^{-1}$ day $^{-1}$ ) and lowest in Hemiselmis sp. (0.28 $\mathrm{mg} \mathrm{DW} \mathrm{L}^{-1}$ day $^{-1}$; Table 1$)$. In terms of biomass production, the studied cryptophytes were not competitive with Nannochloropsis species or commercially grown green algae, which can reach 10-100 times higher volumetric yields $[35,36]$. However, it needs to be kept in mind that, unlike Nannochloropsis and many other algae, cryptophytes do not have strong and heavy cell wall structures, which would also increase their cellular biomass. Thus, the comparisons of biomass yields between different algal classes can be rather misleading. Furthermore, we did not try to optimize the growth rates or biomass production of cryptophytes in this study, and thus cannot fully conclude the inferiority of cryptophytes in terms of biomass production.

Table 1. The studied cryptophyte strains, their codes in culture collection, growth rates (divisions day ${ }^{-1}$ ) and volumetric biomass yields ( $\mathrm{mg}$ dry weight $\mathrm{L}^{-1}$ day ${ }^{-1}$ ). Different letters (a-f) denote significant differences (ANOVA $p<0.05$ ) between strains.

\begin{tabular}{|c|c|c|c|}
\hline Species & Code in Culture Collection & Max. Growth Rate * & Dry Weight (mg L ${ }^{-1}$ Day $\left.^{-1}\right)^{\circ}$ \\
\hline Chroomonas mesostigmatica & CCMP/NCMA 1168 & $0.65(0.03){ }^{a b c}$ & 3.40 \\
\hline Guillardia theta & CCMP/NCMA 2712 & $0.66(0.04)^{\mathrm{a}}$ & 0.56 \\
\hline Hemiselmis sp. & NRC5 & $0.70(0.01)^{\text {abcd }}$ & 0.28 \\
\hline Proteomonas sulcata & CCMP/NCMA 704 & $0.65(0.01)^{\text {abcd }}$ & 1.47 \\
\hline Rhodomonas salina & CCMP/NCMA 757 & $0.51(0.01)$ bcde & 2.79 \\
\hline Storeatula major & $\mathrm{SM}$ or $\mathrm{G}$ & $0.48(0.03)$ bcde & 3.23 \\
\hline Teleaulax acuta & SCCAP K-1486 & $0.34(0.01)^{\mathrm{f}}$ & 1.05 \\
\hline Teleaulax amphioxeia & GCEP01 & $0.55(0.03)^{a b}$ & 2.05 \\
\hline
\end{tabular}

* Detected after 4 days for C. mesostigmatica, 5 days for T. amphioxeia, Hemiselmis sp. and R. salina, and 7 days for G. theta, T. acuta, P. sulcata and S. major. ${ }^{\circ}$ Detected after 5 days for C. mesostigmatica, 7 days for T. amphioxeia, S. major and R. salina, and after 9 days for G. theta, T. acuta, P. sulcata and Hemiselmis sp. 


\subsection{Polyunsaturated Fatty Acids}

The proportion of $\omega-3$ PUFAs ( $73.9 \pm 7.0 \%$ of all FAs) was high in all of the studied strains, which is in accordance with previous studies on cryptophytes and very competitive compared with microalgae in general $[26-28,37]$. The highest $\omega-3$ PUFA proportions were found in S. major ( $81.1 \pm 0.3 \%$ of all FA) and Proteomonas sulcata $(80.3 \pm 1.9 \%$ of all FA). These two strains together with Guillardia theta and Hemiselmis sp. also had the highest amount of $\omega-3$ PUFAs in proportion to dry weight $(4.9 \pm 0.6 \%$ of DW; Table 2).

The contribution of the short-chain ALA (average $51.1 \pm 7.0 \%$ of all FAs) and SDA (average $21.0 \pm 5.8 \%$ of all FAs) varied a little between species, but did not differ statistically between them. However, the proportion of long-chain EPA (average $19.1 \pm 4.6 \%$ of all FAs) varied significantly between the strains, as also did DHA (average $8.8 \pm 4.9 \%$ of all FAs; Table 2 ). The studied marine species had higher EPA and DHA proportions than has been previously found in the brackish cryptophyte Rhodomonas baltica by Patil et al. [35] (EPA $13.1 \%$ and DHA $0.6 \%$ of all FAs). In comparison to freshwater species, marine cryptophytes had equal amount of EPA, but more DHA than freshwater strains $[24,25]$. The combined percentage of EPA and DHA is important for commercial purposes. Together the EPA and DHA of the studied marine cryptophytes represented $20.8 \pm 6.7 \%$ of all FAs, which is competitive to the already commercially employed algae or species suggested as suitable for commercial EPA and DHA production (EPA + DHA range 5-57\% of total FAs) [2,3]. Furthermore, the contribution of EPA and DHA was similar to the reported values of Nannochloropsis sp. $(26.7 \%)$ that has so far been considered to be one of most promising strains for commercial EPA and DHA production [2]. The advantage of marine cryptophytes is that they contain a high proportion of both EPA and DHA, whereas Nannochloropsis species contain mainly EPA [34].

The studies dealing with algal FA production often report results as proportions of PUFAs or total FAs as we also did above. This makes it easy to compare between the strains, but does not actually tell anything about the true gain of the FAs. Thus, we calculated the synthesized amount of FAs and per volume per day $\left(\mu \mathrm{g} \mathrm{L}^{-1} \mathrm{day}^{-1}\right)$. When calculated this way, $S$. major and $C$. mesostigmatica were the best producers of ALA ( $45 \pm 1.1 \mu \mathrm{g} \mathrm{L}{ }^{-1}$ day $^{-1}$; Table 3$)$, even though the highest ALA content $(2.6 \%$ of DW) was found in Hemiselmis sp. Both S. major and C. mesostigmatica produced up to 10 times more ALA daily than any other strain. Similarly, the SDA content was highest in the S. major ( $2.4 \pm 0.01 \%$ of DW) followed by C. mesostigmatica and G. theta. When taking into account the time and volume, S. major and C. mesostigmatica were also the two most efficient producers of SDA $\left(76 \pm 3.3 \mu \mathrm{g} \mathrm{L}^{-1} \mathrm{day}^{-1}\right.$; Table 3), whereas the SDA gain was lowest in G. theta. Due to the four double bond structure of SDA, it does not require the rate-limiting enzyme desaturase to convert to EPA in humans, which means that dietary SDA is a better precursor of EPA than ALA $[38,39]$. Thus, in addition to high EPA, the high SDA content even further increases the value of certain cryptophytes as potential commercial sources of $\omega-3$ PUFAs. However, purely as SDA producers, algae compete with, e.g., soy that can be used for enriched SDA oil production [39]. 
Table 2. The $\omega$-3 fatty acid (FA) contents in mg dry weight (DW) ( $\mu \mathrm{g}$ FA in mg DW) and proportions (\%) as well as the EPA/DHA ratios of the studied cryptophytes and some other algae suggested for commercial lipid production (values derived from literature). ALA $=\alpha$-linolenic acid (18:3: $\omega 3$ ), SDA $=$ stearidonic acid (18:4: $\omega 3$ ),

EPA = eicosapentaenoic acid (20:5: w3), DHA = docosahexaenoic acid (22:6: w3). Different letters (a-g) denote significant differences (ANOVA $p<0.05)$ between strains.

The culture collection codes of the cryptophyte strains can be found in Table 1. Standard deviations for these FAs are shown in Supplemental Table S1.

\begin{tabular}{|c|c|c|c|c|c|c|c|c|c|c|c|c|}
\hline Species & $\begin{array}{l}\text { Total } \omega-3 \mu \mathrm{g} \\
\text { FA in Mg DW }\end{array}$ & $\begin{array}{c}\omega-3 \% \\
\text { of All FAs }\end{array}$ & $\begin{array}{l}\text { ALA } \mu \text { FA } \\
\text { in } \mathrm{Mg} \text { DW }\end{array}$ & $\begin{array}{l}\text { ALA } \% \text { of } \\
\omega-3 \text { FAs }\end{array}$ & $\begin{array}{l}\text { SDA } \mu \text { FA } \\
\text { in Mg DW }\end{array}$ & $\begin{array}{l}\text { SDA } \% \text { of } \\
\omega-3 \text { FAs }\end{array}$ & $\begin{array}{l}\text { EPA } \mu \mathrm{g} \text { FA } \\
\text { in } \mathrm{Mg} \text { DW }\end{array}$ & $\begin{array}{l}\text { EPA } \% \text { of } \\
\omega-3 \text { FAs }\end{array}$ & $\begin{array}{l}\text { DHA } \mu \text { FA } \\
\text { in Mg DW }\end{array}$ & $\begin{array}{c}\text { DHA } \% \text { of } \\
\omega-3 \text { FAs }\end{array}$ & $\begin{array}{c}\text { EPA/DHA } \\
\text { Ratio }\end{array}$ & $\begin{array}{c}\text { EPA + DHA } \% \\
\text { of All FA }\end{array}$ \\
\hline Chroomonas mesostigmatica & $45.5^{\mathrm{abcd}}$ & $71.1^{\mathrm{c}}$ & $13.5^{\mathrm{a}}$ & 60.3 & $21.7^{\mathrm{a}}$ & 17.4 & $9.3^{\mathrm{a}}$ & $20.5^{\mathrm{d}}$ & $0.8^{\mathrm{b}}$ & $1.7^{\mathrm{g}}$ & $11.6^{\mathrm{a}}$ & $15.8^{\mathrm{c}}$ \\
\hline Guillardia theta & $47.8^{\mathrm{ac}}$ & $65.4^{\mathrm{b}}$ & $19.7^{\mathrm{a}}$ & 56.7 & $19.5^{\mathrm{ab}}$ & 25.4 & $7.1^{\mathrm{ab}}$ & $14.9^{\mathrm{a}}$ & $1.4^{\mathrm{b}}$ & $3.0^{\mathrm{e}}$ & $5.1^{\mathrm{b}}$ & $11.7^{\mathrm{d}}$ \\
\hline Hemiselmis sp. & $58.8^{+}$ & $70.1^{+}$ & $26.2^{+}$ & 53.2 & $16.8^{+}$ & 20.5 & $12.5^{+}$ & $21.2^{\mathrm{f}}$ & $3.0^{+}$ & $5.1^{+}$ & $4.2^{+}$ & $18.5^{\mathrm{b}}$ \\
\hline Proteomonas sulcata & $48.2^{b c}$ & $80.3^{\mathrm{a}}$ & $16.4^{\mathrm{a}}$ & 58.5 & $19.4^{\mathrm{ab}}$ & 16.2 & $6.1^{\mathrm{ab}}$ & $12.7^{\mathrm{e}}$ & $6.1^{\mathrm{a}}$ & $12.6^{\mathrm{b}}$ & $1^{\mathrm{c}}$ & $20.4^{\mathrm{b}}$ \\
\hline Rhodomonas salina & 33.7 abd & $64.2^{\mathrm{b}}$ & $8.6^{\mathrm{b}}$ & 48.8 & $15.4^{\mathrm{b}}$ & 22.8 & $5.8^{\mathrm{b}}$ & $17.2^{\mathrm{g}}$ & $3.8^{\mathrm{c}}$ & $11.2^{\mathrm{c}}$ & $0.5^{\mathrm{d}}$ & $18.2^{b c}$ \\
\hline Storeatula major & $51.4^{\mathrm{abc}}$ & $81.1^{\mathrm{a}}$ & $21.5^{\mathrm{d}}$ & 41.9 & $24.3^{\mathrm{a}}$ & 32.1 & $8.2^{\mathrm{ab}}$ & $16.0^{\mathrm{g}}$ & $5.2^{\mathrm{ac}}$ & $10.0^{\mathrm{d}}$ & $1.6^{\mathrm{c}}$ & $21.1^{\mathrm{b}}$ \\
\hline Teleaulax acuta & $25.3^{\mathrm{d}}$ & $79.6^{\mathrm{a}}$ & $3.7^{\mathrm{c}}$ & 46.2 & $11.3^{\mathrm{c}}$ & 13.4 & $6.6^{\mathrm{ab}}$ & $26.0^{\mathrm{c}}$ & $3.6^{c}$ & $14.3^{\mathrm{a}}$ & $1.8^{\mathrm{c}}$ & $32.1^{\mathrm{a}}$ \\
\hline Teleaulax amphioxeia & $36.0^{\mathrm{abcd}}$ & $79.6^{\mathrm{a}}$ & $7.0^{\mathrm{b}}$ & 43.3 & $15.8^{\mathrm{b}}$ & 20.5 & $8.5^{\mathrm{ab}}$ & $23.6^{\mathrm{b}}$ & $4.6^{\mathrm{ac}}$ & $12.7^{\mathrm{b}}$ & $1.8^{\mathrm{c}}$ & $28.9^{\mathrm{a}}$ \\
\hline Nannochloropsis spp. (eustigmatophyte) * & & $7.7-30.8[34]$ & & & & & & $23.4-28$ [2] & & & $<0.06$ [34] & $26.7[2]$ \\
\hline Nitzschia spp. (diatom)* & & $3-9.2[26]$ & & & & & & & & & & \\
\hline Skeletonema spp. (diatom) * & & $16.3-17.6[26]$ & & & & & & & & & & \\
\hline Isochrysis spp. (prymnesiophyte) * & & $30.4-48.1[26,34]$ & & & & & & & & & & \\
\hline Tetraselmis sp. (chlorophyte) * & & $8.4-31.3[34]$ & & & & & & & & & & \\
\hline Dunaliella salina (chlorophyte) * & & & & & & & & $21.4[2]$ & & & & \\
\hline Chroothece richteriana (rhodophyte) * & & 29.4 [37] & & & & & & & & & & $15.9[37]$ \\
\hline
\end{tabular}

${ }^{\dagger}$ Could not be statistically tested. * Values from literature.

Table 3. The daily gain of $\omega-3$ and $\omega-6$ fatty acids and sterols $\left(\mu \mathrm{g} \mathrm{L}{ }^{-1}\right.$ day $\left.{ }^{-1}\right)$ when produced with the studied cryptophytes. ALA $=\alpha$-linolenic acid (18:3: $\left.\omega 3\right)$,

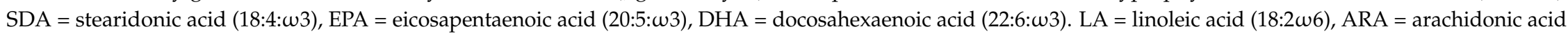
(20:4w6), DPA = docosapentaenoic acid (22:5w6). Different letters (a-d) denote significant differences (ANOVA $p<0.05)$ between strains. The culture collection codes of the cryptophyte strains can be found in Table 1.

\begin{tabular}{|c|c|c|c|c|c|c|c|c|c|c|}
\hline Species & $\begin{array}{c}\text { ALA } \\
\mu \mathrm{L}^{-1} \text { Day }^{-1} \\
\end{array}$ & $\begin{array}{c}\text { SDA } \\
\mu \mathrm{L}^{-1} \text { Day }^{-1} \\
\end{array}$ & $\begin{array}{c}\text { EPA } \\
\mu \mathrm{L}^{-1} \text { Day }^{-1} \\
\end{array}$ & $\begin{array}{c}\text { DHA } \\
\mu \mathrm{L}^{-1} \text { Day }^{-1} \\
\end{array}$ & $\begin{array}{c}\omega-3 \\
\mu \mathrm{L}^{-1} \text { Day }^{-1} \\
\end{array}$ & $\begin{array}{c}\text { LA } \\
\mu \mathrm{g} \mathrm{L}{ }^{-1} \text { Day }^{-1} \\
\end{array}$ & $\begin{array}{c}\text { ARA } \\
\mu \mathrm{L}^{-1} \text { Day }^{-1} \\
\end{array}$ & $\begin{array}{c}\text { DPA } \\
\mu \mathrm{L}^{-1} \text { Day }^{-1} \\
\end{array}$ & $\begin{array}{c}\omega-6 \\
\mu \mathrm{L}^{-1} \text { Day }^{-1}\end{array}$ & $\begin{array}{c}\text { Sterols } \\
\mu \mathrm{g} \mathrm{L} \text { Day }^{-1} \\
\end{array}$ \\
\hline $\begin{array}{l}\text { Chroomonas } \\
\text { mesostigmatica }\end{array}$ & $45.93^{a}$ & $73.83^{a}$ & $31.64^{a}$ & $2.72^{\mathrm{c}}$ & $154.81^{\mathrm{a}}$ & $7.83^{\mathrm{b}}$ & $0.34^{\mathrm{b}}$ & $0.34^{b}$ & $28.92^{b}$ & $4.36^{\mathrm{a}}$ \\
\hline Guillardia theta & $11.00^{\mathrm{b}}$ & $10.89^{c}$ & $3.96^{\mathrm{e}}$ & $0.78^{\mathrm{d}}$ & $26.69^{c}$ & $1.84^{\mathrm{c}}$ & - & $1.17^{\mathrm{a}}$ & $3.13^{c}$ & $0.37^{c}$ \\
\hline Hemiselmis sp. & $7.28^{+}$ & $4.66^{+}$ & $3.47^{+}$ & $0.83^{+}$ & $16.34^{+}$ & $0.72^{+}$ & - & - & $1.14^{+}$ & $0.43^{+}$ \\
\hline Proteomonas sulcata & $24.08^{c}$ & $28.49^{\mathrm{b}}$ & $8.96^{\mathrm{c}}$ & $8.96^{\mathrm{b}}$ & $70.77^{b}$ & $1.03^{\mathrm{cd}}$ & $0.44^{\mathrm{b}}$ & $0.59 \mathrm{ab}$ & $2.50^{\mathrm{c}}$ & $1.04 \mathrm{bc}$ \\
\hline Rhodomonas salina & $23.95^{\mathrm{c}}$ & $42.89^{b}$ & $16.16^{\mathrm{b}}$ & $10.58^{\mathrm{b}}$ & $93.87^{\mathrm{b}}$ & $15.32^{\mathrm{a}}$ & $4.46^{\mathrm{a}}$ & $0.84^{\mathrm{a}}$ & $26.74^{b}$ & $2.73^{\mathrm{b}}$ \\
\hline Storeatula major & $44.26^{\mathrm{a}}$ & $78.50^{\mathrm{a}}$ & $26.49 \mathrm{ab}$ & $16.8^{\mathrm{a}}$ & $166.04^{a}$ & $5.49^{b}$ & $0.65^{\mathrm{b}}$ & - & $43.29^{a}$ & 3.10 ab \\
\hline Teleaulax acuta & $3.89^{\mathrm{d}}$ & $11.87^{\mathrm{c}}$ & $6.93^{\mathrm{d}}$ & $3.78^{\mathrm{c}}$ & $26.57^{c}$ & $0.11^{\mathrm{d}}$ & - & - & $0.21^{\mathrm{d}}$ & $0.37^{c}$ \\
\hline Teleaulax amphioxeia & $14.35^{\mathrm{bc}}$ & $32.39^{\mathrm{b}}$ & $17.43^{b}$ & $9.43^{b}$ & $73.8^{\mathrm{b}}$ & $1.85^{\mathrm{c}}$ & - & - & $2.05^{\mathrm{c}}$ & $0.92^{c}$ \\
\hline
\end{tabular}

${ }^{\dagger}$ Could not be statistically tested. 
The content of EPA was highest $(1.1 \pm 0.2 \%$ of DW) in Hemiselmis sp. and C. mesostigmatica, which is more than previously found in R. baltica or Oocystis sp. (0.11-0.4\% of DW) [35], but less than found from freshwater cryptophytes [24,25]. In relation to gain, S. major and C. mesostigmatica were the two most efficient EPA synthesizers $\left(29 \pm 3.6 \mu \mathrm{g} \mathrm{L}^{-1}\right.$ day $\left.^{-1}\right)$, and their EPA gain was double compared with those of the second-best strains, i.e., Teleaulax amphioxeia and Rhodomonas salina $\left(17 \pm 0.9 \mu \mathrm{g} \mathrm{L}^{-1}\right.$ day $\left.^{-1}\right)$. The DHA content was highest $(0.5 \pm 0.08 \%$ DHA of DW) in P. sulcata, S. major and T. amphioxeia. Their results were similar to previous measurements of freshwater strains, but higher than found in brackish strains [25,35]. However, when calculated as daily gain, C. mesostigmatica was shown to be a poor DHA producer $\left(2.7 \pm 0.2 \mu \mathrm{g} \mathrm{L}^{-1}\right.$ day $\left.^{-1}\right)$, whereas $S$. major was able to synthesize high amounts of DHA $\left(17 \pm 0.2 \mu \mathrm{g} \mathrm{L}^{-1}\right.$ day $\left.^{-1}\right)$. Also, P. sulcata, R. salina and T. amphioxeia were better DHA producers $\left(9.7 \pm 0.8 \mu \mathrm{g} \mathrm{L}^{-1}\right.$ day $\left.^{-1}\right)$ than $C$. mesostigmatica. Thus, among all studied strains, S. major seems to be the superior species for ALA, SDA, EPA, and DHA production.

In commercially available food supplements, the EPA/DHA ratios are around 1.5 [40]. However, the optimal EPA/DHA ratios have not been rigorously examined, and, thus, it is not known if this is the most desirable ratio. Most of the studied cryptophytes had a similar or slightly higher EPA/DHA ratios compared to established commercial products (Table 2), while the highest was observed in C. mesostigmatica (EPA/DHA = 11.6) and lowest in R. salina (EPA/DHA 0.5).

The proportions of $\omega-6$ PUFAs of all FAs varied greatly between strains, and was highest $(19.8 \pm 0.1 \%$ of all FAs) in $R$. salina and lowest $(0.7 \pm 0.01 \%$ of all FAs) in Teleaulax acuta (Table 4$)$. The $\omega-6$ PUFA content (\% of DW) was generally low in all strains $(0.02-1.0 \%$ of DW), but differed significantly among strains. Total $\omega-6$ PUFAs were highest in $R$. salina $(1.0 \pm 0.04 \%$ of $\mathrm{DW})$, but were also high in C. mesostigmatica $(0.53 \pm 0.01 \%$ of DW) and G. theta $(0.56 \pm 0.06 \%$ of DW) (Table 4). The total $\omega-6$ content of $R$. salina was higher than previously reported for freshwater and brackish cryptophytes [25,35]. Usually, such high amounts of $\omega-6$ are found in brown algae [41]. More specifically, the highest contents of LA $(0.6 \pm 0.02 \%$ of DW) and arachidonic acid (ARA; $20: 4 \omega 6$, $0.16 \pm 0.01 \%$ of DW) were found in R. salina. Docosapentaenoic acid (DPA; 22:5w6) concentrations were, in general, very low, and highest in R. salina $(0.03 \pm 0.01 \%$ of DW) and P. sulcata $(0.04 \pm 0.01 \%$ of DW, Table 4). When calculated as daily gain, the highest total $\omega-6$ PUFA was attained in S. major $\left(43 \mu \mathrm{g} \mathrm{L}^{-1}\right.$ day $^{-1}$; Table 3).

Table 4. The $\omega-6$ fatty acid contents ( $\mu$ g FA in mg dry weight) and proportions (\%) of the studied

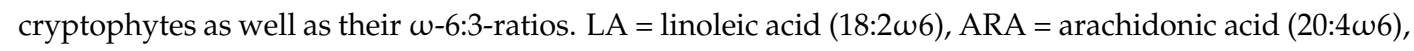
$\mathrm{DPA}=$ docosapentaenoic acid (22:5w6). Different letters (a-f) denote significant differences (ANOVA $p<0.05$ ) between strains. The culture collection codes of the cryptophyte strains can be found in Table 1. Standard deviations for these FAs are shown in Supplemental Table S1.

\begin{tabular}{|c|c|c|c|c|c|c|c|c|c|c|}
\hline Species & $\begin{array}{c}\text { Total } \omega-6 \\
\mu \mathrm{g} \text { FA in } \\
\text { mg DW }\end{array}$ & $\begin{array}{c}\omega-6 \% \text { of } \\
\text { All FA }\end{array}$ & $\begin{array}{l}\omega-6 \% \\
\text { of DW }\end{array}$ & $\begin{array}{c}\omega-6 / \omega-3 \\
\text { Ratio }\end{array}$ & $\begin{array}{l}\text { LA } \mu \mathrm{g} \\
\text { FA in } \\
\text { mg DW }\end{array}$ & $\begin{array}{l}\text { LA } \% \text { of } \\
\omega-6 \text { FAs }\end{array}$ & $\begin{array}{l}\text { ARA } \mu \mathrm{g} \\
\text { FA in } \\
\text { mg DW }\end{array}$ & $\begin{array}{l}\text { ARA } \% \text { of } \\
\omega-6 \text { FAs }\end{array}$ & $\begin{array}{l}\text { DPA } \mu \mathrm{g} \\
\text { FA in } \\
\text { mg DW }\end{array}$ & $\begin{array}{c}\text { DPA } \% \text { of } \\
\omega-6 \text { FAs }\end{array}$ \\
\hline Chroomonas mesostigmatica & $8.5^{\mathrm{d}}$ & $13.3^{\mathrm{b}}$ & $0.9^{\mathrm{b}}$ & $1: 5^{\mathrm{e}}$ & $2.3^{\mathrm{b}}$ & $26.8^{g}$ & $0.06^{\mathrm{a}}$ & $0.7^{\mathrm{f}}$ & $0.1^{\mathrm{d}}$ & $70.4^{\mathrm{a}}$ \\
\hline Hemiselmis sp. & $4.1^{+}$ & $4.9^{+}$ & $0.4^{+}$ & $1: 14^{+}$ & $2.6^{+}$ & $62.8^{+}$ & $0.02^{+}$ & $0.4^{+}$ & $1.5^{+}$ & $35.3^{+}$ \\
\hline Proteomonas sulcata & $1.7^{\mathrm{a}}$ & $2.9^{\mathrm{e}}$ & $0.2^{d}$ & $1: 28^{c}$ & $0.7^{\mathrm{a}}$ & $43.6^{\mathrm{e}}$ & $0.31^{b}$ & $18.2^{\mathrm{a}}$ & $0.4^{\mathrm{b}}$ & $24.0^{\mathrm{c}}$ \\
\hline Rhodomonas salina & $10.4^{\mathrm{e}}$ & $19.8^{\mathrm{a}}$ & $1.0^{\mathrm{a}}$ & $1: 3^{e}$ & $5.5^{\mathrm{d}}$ & $53.1^{\mathrm{d}}$ & $1.62^{\mathrm{d}}$ & $15.5^{b}$ & $0.3^{\mathrm{b}}$ & $2.4^{\mathrm{d}}$ \\
\hline Teleaulax acuta & $0.2^{\mathrm{c}}$ & $0.7^{\mathrm{g}}$ & $0.02 \mathrm{e}$ & $1: 126^{\mathrm{a}}$ & $0.1^{\mathrm{a}}$ & $34.9^{f}$ & $0.01^{\mathrm{c}}$ & $4.9^{\mathrm{d}}$ & $0.01^{\mathrm{d}}$ & $0.01^{\mathrm{e}}$ \\
\hline Teleaulax amphioxeia & $1.0^{\mathrm{a}}$ & $2.3^{f}$ & $0.1^{\mathrm{d}}$ & $1: 36^{b}$ & $0.9^{\mathrm{a}}$ & $89.6^{\mathrm{a}}$ & $0.03^{c}$ & $3^{e}$ & $0.01^{\mathrm{d}}$ & $0.01^{\mathrm{e}}$ \\
\hline
\end{tabular}

Modern western diets are deficient in $\omega-3$ PUFAs, but have excessive amounts of $\omega-6$. Thus, supplemental products are needed for amending the high $\omega-6 / \omega-3$ ratios. In the studied cryptophytes, the lowest $\omega-6 / \omega-3$ ratio was found in T. acuta (1:126) and the highest in R. salina (1:3; Table 4). These values are well below the suggested dietary $\omega-6 / \omega-3$ ratio (1-4:1) [11], and substantially lower than reported for some brown algae (up to 3.8:1) [41]. Thus, despite the surprisingly high $\omega-6$ 
PUFA concentrations in some of studied cryptophytes, all of them are suitable for commercial PUFA production and especially for products that are designed for balancing the dietary $\omega-6 / \omega-3$ ratios.

\subsection{Phytosterols}

Three different phytosterols (crinosterol, brassicasterol, and stigmasterol) were found in the studied cryptophytes (Table 5). Crinosterol and brassicasterol are known to act as anti-ageing factors [42], whereas stigmasterol is reported to be most valuable of the phytosterols and have anti-inflammatory effects, preventing, for example, osteoarthritis $[15,17]$. In general, the total sterol concentrations were low in the studied cryptophytes $(0.09 \pm 0.04 \%$ of DW), and only C. mesostigmatica contained all of the three observed sterols (Table 5). Thus, the daily gains were low (range $0.37-4.36 \mu \mathrm{g} \mathrm{L}^{-1} \mathrm{day}^{-1}$; Table 3 ). The obtained results are in line with the ones reported for diatoms (total sterols $0.06-0.57 \%$ of DW) [43], but significantly lower than reported for seaweeds $(0.6-2.3 \%$ of DW) [44]. This suggests that the studied cryptophytes-or perhaps algae in general-are not suitable for profitable sterol production. However, due to the general benefits of phytosterols in human health, even low sterol contents may improve their value as ingredients for functional foods or nutraceuticals $[15,16]$.

Table 5. The sterol contents ( $\mu \mathrm{g}$ sterol in mg dry weight) of the studied cryptophytes. Different letters $(\mathrm{a}-\mathrm{e})$ denote significant differences (ANOVA $p<0.05$ ) between strains. The culture collection codes of the cryptophyte strains can be found in Table 1.

\begin{tabular}{|c|c|c|c|c|}
\hline Species & $\begin{array}{l}\text { Crinosterol } \mu \mathrm{g} \\
\text { ste in mg DW }\end{array}$ & $\begin{array}{l}\text { Brassicasterol } \mu \mathrm{g} \\
\text { ste in mg DW }\end{array}$ & $\begin{array}{l}\text { Stigmasterol } \mu \mathrm{g} \\
\text { ste in mg DW }\end{array}$ & $\begin{array}{l}\text { Sum of Sterols } \mu \mathrm{g} \\
\text { ste in mg DW }\end{array}$ \\
\hline Chroomonas mesostigmatica & $0.93^{\mathrm{a}}$ & $0.02^{\mathrm{c}}$ & $0.33^{\mathrm{a}}$ & $1.28^{\mathrm{a}}$ \\
\hline Guillardia theta & nd & $0.31^{b}$ & $0.36^{\mathrm{a}}$ & $0.67^{c}$ \\
\hline Hemiselmis sp. & $0.43^{+}$ & $1.11^{\dagger}$ & nd & $1.54^{+}$ \\
\hline Proteomonas sulcata & nd & $0.71^{\mathrm{a}}$ & nd & $0.71^{b c}$ \\
\hline Rhodomonas salina & $0.14^{\mathrm{c}}$ & $0.84^{\mathrm{a}}$ & nd & $0.98^{a b}$ \\
\hline Storeatula major & $0.24^{\mathrm{c}}$ & $0.72^{\mathrm{a}}$ & nd & $0.96^{\mathrm{ab}}$ \\
\hline Teleaulax acuta & nd & $0.35^{\mathrm{b}}$ & nd & $0.35^{\mathrm{e}}$ \\
\hline Teleaulax amphioxeia & $0.45^{b}$ & nd & nd & $0.45^{\mathrm{d}}$ \\
\hline
\end{tabular}

nd $=$ not detected. ${ }^{\dagger}$ Could not be statistically tested.

\section{Materials and Methods}

\subsection{Growth Rate and Biomass Production}

The eight marine cryptophyte strains (Table 1) were grown in F/2 medium in $400 \mathrm{~mL}$ plastic tissue culture flasks. Each strain had two replicates, which were kept at $15{ }^{\circ} \mathrm{C}$ and under a $14 \mathrm{~h}: 10 \mathrm{~h}$ light/dark cycle at a light level of $50 \mu \mathrm{mol}$ quanta s $\mathrm{s}^{-1} \mathrm{~m}^{-2}$. The growth rates were calculated for the exponential growth phase using three sampling points and Equation (1). Biomass production (as mg dry weight $\mathrm{L}^{-1} \mathrm{day}^{-1}$ ) of the cultures was determined from freeze-dried samples taken at the time of lipid sampling near the end of the exponential growth phase.

$$
\mu=\ln \left(\text { cells }_{\mathrm{Tx}} / \text { cells }_{\mathrm{T} 0}\right)
$$

\subsection{Lipid Extraction}

The samples for lipid analyses were collected by centrifugation (3200 rpm for $10 \mathrm{~min}$ ) near the end of the exponential growth phase. The obtained pellets were placed into $-80^{\circ} \mathrm{C}$ until freeze-drying. The lipids were extracted from the freeze-dried samples no longer than three weeks after the sampling. Two replicates of homogenized biomass samples (1-3 mg) were extracted using chloroform/methanol 2:1 (by vol). Samples were sonicated for $10 \mathrm{~min}$ to maximize extraction results, after which samples 
were vortexed and centrifuged for $5 \mathrm{~min}$ at $2000 \mathrm{rpm}$. The liquid part was divided into two equal parts, one of which was used for fatty acid analysis and the other for sterol analysis.

\subsection{Fatty Acid Transesterification and Analysis by GC-MS}

Toluene and $1 \%$ sulfuric acid in methanol were used for the transesterification of fatty acid methyl esters (FAME). The samples were heated at $90{ }^{\circ} \mathrm{C}$ for $90 \mathrm{~min}$, after which $1.5 \mathrm{~mL}$ of $2 \%$ of $\mathrm{KHCO}_{3}$ and $2 \mathrm{~mL}$ hexane was added. The tubes were vortexed and centrifuged ( $2 \mathrm{~min}$ at $1500 \mathrm{rpm}$ ) and the upper layer was collected for analysis. FAMEs were analyzed with a gas chromatograph (Shimadzu Ultra, Kyoto, Japan) equipped with mass detector (GC-MS), using helium as a carrier gas and an Agilent ${ }^{\circledR}$ (Folsom, CA, USA) DB-23 column $(30 \mathrm{~m} \times 0.25 \mathrm{~mm} \times 0.15 \mu \mathrm{m})$. Fatty acids were identified by the retention times (RT) and using specific ions [24]. All of the detected fatty acids and their concentrations (as in $\mu \mathrm{g}$ FA in mg DW) in the studied cryptophyte strains are shown in Supplementary Table S1.

\subsection{Silylation of Sterols and Analysis by GC-MS}

The extracted lipids were diluted in $100 \mu \mathrm{L}$ of pyridine and silylated with $70 \mu \mathrm{L}$ of $N, O-$ bis[trimethylsilyl trifluoroacetamide] (BSTFA), trimethylchlorosilane (TMCS) at $70{ }^{\circ} \mathrm{C}$. Trimethylsilyl (TMS) derivatives of sterols were analyzed with GC-MS (Shimadzu) equipped with A Phenomenex (Torrance, CA, USA) ZB-5 Guardian column $(30 \mathrm{~m} \times 0.25 \mathrm{~mm} \times 0.25 \mu \mathrm{m})$. Sterols were identified using characteristic ions [45].

\subsection{Statistics}

The differences between the growth rates and lipid production between the cryptophyte strains were studied with ANOVA and Tukey's honestly significant difference (HSD) post hoc test. Levene's test was used for testing the homogeneity of variances. All the statistical analyses were performed using R (stats packages: AOV, and TukeyHSD functions) [46] or IBM SPSS Statistics 22 for Windows (IBM Corp., Armonk, NY, USA).

\section{Conclusions}

The increasing interest in exploiting microalgae as a source of commercial products with positive health effects has led to an ongoing search for high production potential of, e.g., essential lipids. In this study we focused on $\omega-3$ and $\omega-6$ PUFAs as well as sterol production by eight marine cryptophytes. Cryptophytes do not have a recalcitrant cell wall, and, thus, they are easier to break and process further for commercial purposes than many of the already commercially employed algae. In addition, the cultivation of marine species for nutritional purposes can utilize non-arable lands and water resources considered unsuitable for agriculture or direct human consumption. We conclude that the marine cryptophytes offer a great source of EPA, DHA, and other $\omega$-3 PUFAs, and that, in comparison to freshwater species, marine cryptophytes have more DHA. We found that cryptophytes also produce $\omega-6$ PUFAs, but their proportion is low compared to that of $\omega-3$ PUFAs, which is beneficial especially for dietary products targeted to lower $\omega-6 / \omega-3$ ratios. When considering both the biomass yield and the yield of the lipids, C. mesostigmatica was the most promising strain for EPA production, whereas S. major seems promising for both EPA and DHA production. These two strains also had the highest sterol gains. However, the purpose of this study was not to optimize growth conditions, and, thus, the other studied strains could likely show even higher growth rates and biomass and lipid yields under optimized conditions.

Supplementary Materials: The following are available online at www.mdpi.com/1660-3397/16/1/3/s1, Table S1: Fatty acid profiles of the studied cryptophyte strains. Concentrations are in $\mu \mathrm{g}$ FA in $\mathrm{mg}$ DW ( \pm is for standard deviations).

Acknowledgments: This research was supported by the Finnish Cultural Foundation research grant awarded to Elina Peltomaa and a National Science Foundation grant (NSF 1436169) awarded to Matthew Johnson. 
Author Contributions: E.P. and S.J.T. designed the study and M.D.J. performed the growth experiments. S.J.T. analyzed the lipid samples and the obtained data together with E.P. E.P. wrote the paper together with M.D.J. and S.J.T.

Conflicts of Interest: The authors declare no conflict of interest.

\section{References}

1. Brown, M.R.; Jefferey, S.W.; Volkman, J.K.; Dunstan, G.A. Nutritional properties of microalgae for mariculture. Aquaculture 1997, 151, 315-331. [CrossRef]

2. Adarme-Vega, T.C.; Lim, D.K.Y.; Timmins, M.; Vernen, F.; Li, Y.; Schenk, P.M. Microalgal biofactories: A promising approach towards sustainable omega-3 fatty acid production. Microb. Cell Fact. 2012, 11, 96. [CrossRef] [PubMed]

3. Martins, D.A.; Custódio, L.; Barreira, L.; Pereira, H.; Ben-Hamadou, R.; Varela, J.; Abu-Salah, K.M. Alternative Sources of n-3 Long-Chain Polyunsaturated Fatty Acids in Marine Microalgae. Mar. Drugs 2013, 11, 2259-2281. [CrossRef] [PubMed]

4. Burdge, G.C.; Calder, P.C. Conversion of $\alpha$-linolenic acid to longer-chain polyunsaturated fatty acids in human adults. Reprod. Nutr. Dev. 2005, 45, 581-597. [CrossRef] [PubMed]

5. Hixson, S.M.; Sharma, B.; Kainz, M.J.; Wacker, A.; Arts, M.T. Production, distribution, and abundance of long-chain omega-3 polyunsaturated fatty acids: A fundamental dichotomy between freshwater and terrestrial ecosystems. Environ. Rev. 2015, 23, 414-424. [CrossRef]

6. Ryckebosch, E.; Muylaert, K.; Foubert, I. Optimization of an analytical procedure for extraction of lipids from microalgae. J. Am. Oil Chem. Soc. 2012, 89, 189-198. [CrossRef]

7. Keen, H.; Payan, J.; Allawi, J.; Walker, J.; Jamal, G.A.; Weir, A.I.; Henderson, L.M.; Bissessar, E.A.; Watkins, P.J.; Sampson, M.; et al. Treatment of diabetic neuropathy with gamma-linolenic acid. The gamma-Linolenic Acid Multicenter Trial Group. Diabetes Care 1993, 16, 8-15. [CrossRef] [PubMed]

8. Johnson, M.; Östlund, S.; Fransson, G.; Kadesjö, B.; Gillberg, C. Omega-3/Omega-6 fatty acids for attention deficit hyperactivity disorder. J. Atten. Disord. 2009, 12, 394-401. [CrossRef] [PubMed]

9. Simopoulos, A.P. The importance of the omega-6/omega-3 fatty acid ratio in cardiovascular disease and other chronic diseases. Exp. Biol. Med. 2008, 233, 674-688. [CrossRef] [PubMed]

10. Anderson, B.M.; Ma, D.W. Are all n-3 polyunsaturated fatty acids created equal? Lipids Health Dis. 2009, 8, 33. [CrossRef] [PubMed]

11. Molendi-Coste, O.; Legry, V.; Leclercq, I.A. Why and how meet n-3 PUFA dietary recommendations? Gastroenterol. Res. Pract. 2011, 2011, 364040. [CrossRef] [PubMed]

12. Simopoulos, A.P. An Increase in the Omega-6/Omega-3 Fatty Acid Ratio Increases the Risk for Obesity. Nutrients 2016, 8, 128. [CrossRef] [PubMed]

13. Gester, H. Can adults adequately convert alpha-linolenic acid (18:3n-3) to eicosapentaenoic acid (20:5n-3) and docosahexaenoic acid (22:6n-3)? Int. J. Vitam. Nutr. Res. 1998, 68, 159-173.

14. Cuellar-Bermudez, S.P.; Aguillar-Hernandez, I.; Cardenas-Chavez, D.L.; Ornelas-Soto, N.; Romero-Ogawa, M.A.; Parra-Saldivar, R. Extraction and purification of high-value metabolites from microalgae: Essential lipids, estaxanthin and phycobiliproteins. Microb. Biotechnol. 2014, 8, 190-209. [CrossRef] [PubMed]

15. Gabay, O.; Sanchez, C.; Salvat, C.; Chevy, F.; Breton, M.; Nourissat, G.; Wolf, C.; Jacques, C.; Berenbaum, F. Stigmasterol: A phytosterol with potential anti-osteoarthritic properties. Osteoarthr. Cartil. 2010, 18, $106-116$. [CrossRef] [PubMed]

16. Burg, V.K.; Grimm, H.S.; Rothhaar, T.L.; Grösgen, S.; Hundsdörfer, B.; Haupenthal, V.J.; Zimmer, V.C.; Mett, J.; Weingärtner, O.; Laufs, U.; et al. Plant sterols the better cholesterol in Alzheimer's disease? A mechanistical study. J. Neurosci. 2013, 33, 16072-16087. [CrossRef] [PubMed]

17. Tang, J.J.; Li, J.G.; Qi, W.; Qiu, W.W.; Li, P.S.; Li, B.L.; Song, B.L. Inhibition of SREBP by a small molecule, betulin, improves hyperlipidemia and insulin resistance and reduces atherosclerotic plaques. Cell Metab. 2011, 13, 44-56. [CrossRef] [PubMed]

18. Moghadasian, M.H.; Frohlich, J.J. Effects of dietary phytosterols on cholesterol metabolism and atherosclerosis: Clinical and experimental evidence. Am. J. Med. 1999, 107, 588-594. [CrossRef]

19. Ma, X.-N.; Chen, T.-P.; Yang, B.; Liu, J.; Chen, F. Lipid Production from Nannochloropsis. Mar. Drugs 2016, 14, 61. [CrossRef] [PubMed] 
20. Nichols, P.D.; Petrie, J.; Singh, S. Long-Chain Omega-3 Oils-An Update on Sustainable Sources. Nutrients 2010, 2, 572-585. [CrossRef] [PubMed]

21. Pulz, O.; Gross, W. Valuable products from biotechnology of microalgae. Appl. Microbiol. Biotechnol. 2004, 65, 635-648. [CrossRef] [PubMed]

22. Doust, A.B.; Wilk, K.E.; Curmi, P.M.G.; Scholes, G.D. The photophysics of cryptophyte light-harvesting. J. Photochem. Photobiol. A 2006, 184, 1-17. [CrossRef]

23. Seixas, P.; Coutinho, P.; Ferreira, M.; Otero, A. Nutritional value of the cryptophyte Rhodomonas lens for Artemia sp. J. Exp. Mar. Biol. Ecol. 2009, 381, 1-9. [CrossRef]

24. Taipale, S.J.; Vuorio, K.; Strandberg, U.; Kahilainen, K.K.; Järvinen, M.; Hiltunen, M.; Peltomaa, E.; Kankaala, P. Lake eutrophication and brownification downgrade availability and transfer of essential fatty acids for human consumption. Environ. Int. 2016, 96, 156-166. [CrossRef] [PubMed]

25. Peltomaa, E.T.; Aalto, S.L.; Vuorio, K.M.; Taipale, S.J. The importance of phytoplankton biomolecule availability for secondary production. Front. Ecol. Evol. 2017, 5, 128. [CrossRef]

26. Renaud, S.M.; Thinh, L.-V.; Lambrinidis, G.; Parry, D.L. The gross chemical composition and fatty acid composition of 18 species of tropical Australian microalgae for possible use in mariculture. Aquaculture 1999, 170, 147-159. [CrossRef]

27. Renaud, S.M.; Thinh, L.-V.; Lambrinidis, G.; Parry, D.L. Effect of temperature on growth, chemical composition and fatty acid composition of tropical Australian microalgae grown in batch cultures. Aquaculture 2002, 211, 195-214. [CrossRef]

28. Dunstan, G.A.; Brown, M.R.; Volkman, J.K. Cryptophyceae and Rhodophyceae; chemotaxonomy, phylogeny, and application. Phytochemistry 2005, 66, 2557-2570. [CrossRef] [PubMed]

29. Butterwick, C.; Heaney, S.I.; Talling, J.F. Diversity in the influence of temperature on the growth rates of freshwater algae, and its ecological relevance. Freshw. Biol. 2004, 50, 291-300. [CrossRef]

30. Kunath, C.; Jakob, T.; Wilhelm, C. Different phycobilin antenna organisations affect the balance between light use and growth rate in the cyanobacterium Microcystis aeruginosa and in the cryptophyte Cryptomonas ovata. Photosynth. Res. 2012, 111, 173-183. [CrossRef] [PubMed]

31. Lewitus, A.J.; Caron, D.A. Relative effects of nitrogen or phosphorus depletion and light intensity on the pigmentation, chemical composition, and volume of Pyrenomonas salina (Cryptophyceae). Mar. Ecol. Prog. Ser. 1990, 61, 171-181. [CrossRef]

32. Scholz, M.J.; Weiss, T.L.; Jinkerson, R.E.; Jing, J.; Roth, R.; Goodenough, U.; Posewitz, M.C.; Gerken, H.G. Ultrastructure and Composition of the Nannochloropsis gaditana Cell Wall. Eukaryot. Cell 2014, 13, 1450-1464. [CrossRef] [PubMed]

33. Bolen, P.; van Dijk, R.; Sinninghe Damsté, J.P.; Rijpstra, W.I.C.; Buma, A.G.J. On the potential application of polar and temperate marine microalgae for EPA and DHA production. AMB Express 2013, 3, 26. [CrossRef] [PubMed]

34. Huerliman, R.; de Nys, R.; Hiemann, K. Growth, lipid content, productivity, and fatty acid composition of tropical microalgae for scale-up production. Biotechnol. Bioeng. 2010, 107, 245-257. [CrossRef] [PubMed]

35. Patil, V.; Källqvist, T.; Olsen, E.; Vogt, G.; Gislerød, H.R. Fatty acid composition of 12 microalgae for possible use in aquaculture feed. Aquac. Int. 2007, 15, 1-9. [CrossRef]

36. Krzeminska, I.; Pawlik-Skowronska, B.; Trzcinska, M.; Tys, J. Influence of photoperiods on the growth rate and biomass productivity of green microalgae. Bioprocess Biosyst. Eng. 2014, 37, 735-741. [CrossRef] [PubMed]

37. Aboal, M.; González-Silvera, D.; Roldán, M.; Hernández-Mariné, M.; López-Jiménez, J.Á.; Whitton, B.A. The freshwater alga Chroothece richteriana (Rhodophyta) as a potential source of lipids. Food Chem. 2014, 162, 143-148. [CrossRef] [PubMed]

38. James, M.J.; Ursin, V.M.; Cleland, L.G. Metabolism of stearidonic acid in human subjects: Comparison with the metabolism of other n-3 fatty acids. Am. J. Clin. Nutr. 2003, 5, 1140-1145.

39. Deckelbaum, R.J.; Torrejon, C. The omega-3 fatty acid nutritional landscape: Health benefits and sources. J. Nutr. 2012, 142, 587S-591S. [CrossRef] [PubMed]

40. Kris-Etherton, P.M.; Grieger, J.A.; Etherton, T.D. Dietary reference intake for DHA and EPA. Prostaglandins Leukot. Essent. Fat. Acids 2009, 81, 99-104. [CrossRef] [PubMed]

41. Silva, G.; Pereira, R.B.; Valentão, P.; Andrade, P.B.; Sousa, C. Distinct fatty acid profile of ten brown macroalgae. Braz. J. Pharmacogn. 2013, 23, 608-613. [CrossRef] 
42. Sun, Y.; Lin, Y.; Cao, X.; Xiang, L.; Qi, J. Sterols from Mytilidae Show Anti-Aging and Neuroprotective Effects via Anti-Oxidative Activity. Int. J. Mol. Sci. 2014, 15, 21660-21673. [CrossRef] [PubMed]

43. Orcutt, D.M.; Patterson, G.W. Sterol, fatty acid and elemental composition of diatoms grown in chemically defined media. Comp. Biochem. Physiol. 1975, 50, 579-583. [CrossRef]

44. Sánchez-Machado, D.I.; López-Cervantes, J.; López-Hernández, J.; Paseiro-Losada, P. Fatty acids, total lipid, protein and ash contents of processed edible seaweeds. Food Chem. 2004, 85, 439-444. [CrossRef]

45. Taipale, S.J.; Hiltunen, M.; Vuorio, K.; Peltomaa, E. Suitability of phytosterols alongside fatty acids as chemotaxonomic biomarkers for phytoplankton. Front. Plant Sci. 2016, 7, 212. [CrossRef] [PubMed]

46. R Development Core Team. R: A Language and Environment for Statistical Computing; R Foundation for Statistical Computing: Vienna, Austria, 2012.

2017 by the authors. Licensee MDPI, Basel, Switzerland. This article is an open access article distributed under the terms and conditions of the Creative Commons Attribution (CC BY) license (http:// creativecommons.org/licenses/by/4.0/). 